\title{
ANALYSIS OF LOCAL BRANDING TO DEVELOP PLACE BRANDING OF PURWAKARTA REGENCY
}

\author{
Susie Perbawasari ${ }^{1}$, Susanne Dida ${ }^{2}$, Aat Ruchiat Nugraha ${ }^{3}$, \\ Achwan Noorlistyo Adi $^{4}$, Aang Koswara ${ }^{5}$ \\ $\left\{{ }^{1}\right.$ susie.perbawasari@unpad.ac.id $\}$ \\ ${ }^{1,2,3,4}$ Padjadjaran University, Indonesia \\ ${ }^{5}$ Ludwig-Maximilians University, Indonesia
}

\begin{abstract}
The existence of a brand becomes essential in building the identity of a product or service of an institution. One form of a brand strategy used to support the increasing number of tourist destinations is place branding. This branding strategy can also be implemented to support the aspects of regional development. The expected aim is to provide a positive image and reputation for the development progress that is being carried out by the regional government. Purwakarta Regency is one of the districts that is active in the development process based on a Sundanese cultural character, which has been initiated and carried out since the leadership of Regent Dedi Mulyadi until now. It is conducted to translate the vision and mission of the district government. This research uses a quantitative method with questionnaires as the data collection instrument. The results show that the community considers that Purwakarta Regency's development has shown regional identity that can have a positive impact on Purwakarta regency. It is indicated by the presence and characteristics of Sundanese in the pattern of development in infrastructure and mental character within the Purwakarta district government environment. The conclusions in this study indicate that as many as $52 \%$ of the respondents state that Purwakarta regency has a unique place branding characteristic that characterizes a strong Sundanese so that it receives a positive response from the community.
\end{abstract}

Keywords: Local Branding, Place Branding, Sundanese Character, Purwakarta Regency

\section{INTRODUCTION}

Lately, the government in regencies/cities is active in the development of their regions to increase local revenue. Along with the development of an era of regional autonomy that is increasingly strong, the district/city government seeks to have a brand that is easily known by all levels of society. Through a brand that is easily known in the community will facilitate the public to get information about the existence of an area to be used as a tourist destination and other destinations. And through the brand is also needed as a distinctive identity with others. So that now more and more institutions realize that brands are precious assets and need to be managed as well as possible to be able to attract the attention of the public. This is in line with what was said by [1] that building a regional image is not accessible if there is no identity and identifier of the area known by the community.

Purwakarta as an area with regency status in West Java province, for more than ten years, has built various public facilities based on cultural values as Agus Hasan S. stated this as Head of the Department of Youth, Sports, Tourism and Culture of Purwakarta Regency who said 
that since the leadership of the Regent Dedi Mulyadi, the Purwakarta government is actively undertaking development that is characterized by Sundanese cultural values that can attract people outside the region to visit Purwakarta. The arrival of people from various layers into the Purwakarta region had a good impact on the economic development of the Purwakarta community. The number of tourists visiting Purwakarta is inseparable from the regional brand built by the Purwakarta district government. The concept of this brand is very relevant and needed by an area in terms of being able to attract the sympathy of tourists, attract investors and even exporters to carry out their business activities.

Some uniqueness that makes Purwakarta visited by many domestic and foreign tourists is the arrangement of park buildings and infrastructure characterized by Sundanese values, the formation of the character of education and public services based on the potential regional insight that can form a favourable impression felt by the public. So, Purwakarta Regency is very worthy of being made as one of the regencies that have a big hand in promoting tourism both in West Java Province and Indonesia. Purwakarta is not only rich in tourist attractions but also rich in culture within the community [2]. The creation of Purwakarta tourism progress in addition to the support of specific tourism promotion strategies is also supported by the contribution of the Purwakarta community that has been neutralizing various "uniqueness" of places owned by Purwakarta regency. The existence of a viral posting somewhere delivered by nettizen in cyberspace can be a source of further inspiration for the mainstream media to be used as a source of news that meets journalistic rules. The evaluation of a place can occur, including the Purwakarta region because of the element of community intervention as the main actor in building a Purwakarta identity that is "unique" to be used as a new tourist destination in West Java. The predicate as a new tourist destination for Purwakarta regency needs to be continuously socialized by the Purwakarta public in achieving mutual prosperity. To be able to realize the ideals of prosperity for the people of Purwakarta from the results of the predicate as a new tourist destination, we need a positive perception that is formed in the minds of the public target.

The importance of perception becomes the main thing in communicating activities that are being carried out or that have already been done. The perception assessment can be seen from the vision, mission, and policies carried out by an institution in creating products or services, including government agencies. The Purwakarta district government as part of the government institution has its efforts regarding the results of development achievements that have been carried out so far to have an impact on increasing the development index felt by the community. The existence of the population is essential because it becomes a subject and object of development which is the backbone of the implementation of activities carried out by the government. Because reputation is formed as a result of the performance of a long-term institution will develop a particular image in the minds of the community [3]. So, this is where the importance of a perception formed in the minds of the public. It is to know the positioning of an institution in the minds of the people. Referring to Aaker (2000) who states that in a very competitive market situation, the brand plays an even more critical role than the product [3].

As a district area, Purwakarta can transform into a regional area that combines aspects of culture and technology in carrying out its development. This Purwakarta development concept has encouraged various publics to entrust their "business" choices in the area. With capital raising and developing regional cultural potential as branding, Purwakarta regency has now turned into an area that is ready to compete with other cities/regencies in West Java to gain sympathy and public visits to Purwakarta with the slogan "Purwakarta Istimewa" (Special Purwakarta). And the concept of branding is seen as an essential factor in differentiating local products/services of an area from external competitors by utilizing the cultural uniqueness 
inherent in the product and its quality elements. According to Natarajan and Thiripurasundari (2010) who defines a local brand as a brand that exists in a country brand or in a limited geographical area where there is a link between the national economy and individual welfare towards global market competition [4].

The existence of local branding for an area, especially for Purwakarta regency, is one of the advantages of regency government in West Java that can give added value in the form of strong Sundanese when compared to other regency/city areas in West Java. This is in line with what de Chernatony and McDonald (1992) say in [5] that the difference between brands and commodities can be summarized in the phrase "added value" where this added value is the wealth created by the institution with its own efforts. So, the added value is usually implied in a brand where the brand itself is a mechanism to achieve competitive advantage for institutions by utilizing differentiation.

Thus, this study aims to determine and explain the analysis of local branding which was built by the Purwakarta regency government in an effort to make the Purwakarta area a new tourist destination in West Java province.

\section{RESEARCH METHOD}

The method approach used for this research is a quantitative method, where the quantitative method will be examined in general about the description of variables using statistical formulas that are frequency tabulation about social phenomena. The quantitative research design used is conclusive research, namely analyzing phenomena that seek to answer the problem by referring to the previous concepts that are descriptive and explanatory [5]. Quantitative approaches are more concerned with measurement and sampling methods because they use a deductive approach that emphasizes detailed priorities in the collection and analysis of data. To analyze useful data, valid or truthful data are needed by collecting directly through the distribution of question questionnaires to the public target, namely the Purwakarta community. While other supporting data (secondary) through interviews and literature review in the form of literature, leading journals, magazines, newspapers, information from related institutions, internet sites that can provide information following research problems.

The population of this research is the people who live Purwakarta who have known and felt about the process of infrastructure development and basic public services carried out by the government so far. The samples in this study are students, college students, private workers, and civil servants who live in Purwakarta, Plered, Sukatani, Wanayasa, and Bungursari sub-districts that researchers take with the criteria of the community who have visited and or lived in Purwakarta regency. They are selected based on a simple random sampling technique totaling 100 people.

\section{RESULT AND DISCUSSION}

Giving a brand (branding) to the region is an effort to introduce to the outside world about the potential that must be managed and appropriately utilized for the common welfare. This branding can be considered as a powerful tool to give the characteristics of a product with other products. Branding itself is the process of creating something that can be recognized by the target public about who says who you are and what your business represents. Branding at a regional location has become a reason, especially for Purwakarta regency, to continue to strengthen and develop branding elements that are characterized by the Purwakarta region as 
part of the Priangan land. The following results of research on local branding Purwakarta district: 


\section{Respondents Data}

Table 1.

Frequency Distribution of Respondents by Age

\begin{tabular}{rcc}
\hline Age & Frequency & Percentage \\
\hline$<20$ years old & 2 & $2 \%$ \\
$21-29$ years old & 53 & $53 \%$ \\
$30-39$ years old & 19 & $19 \%$ \\
$40-49$ years old & 8 & $8 \%$ \\
$>50$ years old & 18 & $18 \%$ \\
\hline Total & $\mathbf{1 0 0}$ & $\mathbf{1 0 0 \%}$ \\
\hline
\end{tabular}

Source: Research Result, 2019

Respondents in this study are the respondents with a group of teens to elders. This grouping of respondents can be seen in table 1 which is divided into 5 criteria; they are age $<20$ years by $2 \%$ ( 2 people), ages $21-29$ years by $53 \%$ (53 people), ages $30-39$ years by $19 \%$ (19 people), age $40-49$ years by $8 \%$ ( 8 people) and age $>50$ years as many as $18 \%$ (18 people). Thus, it can be concluded that almost the majority of people who can feel and enjoy the atmosphere of development results in Purwakarta Regency are those who are still around 21-29 years old, whom incidentally can behave as a young person who is full of desire to gain experience by looking at the situation and conditions in the surrounding environment, including paying attention to the processes and results of development that occur in an area.

Table 2. Respondents' Education

\begin{tabular}{|c|c|c|}
\hline Educations & Frequency & Percentage \\
\hline Elementary school / equivalent & 1 & $1 \%$ \\
\hline Junior High School/ equivalent & 1 & $1 \%$ \\
\hline $\begin{array}{l}\text { Senior high school/Vocational high } \\
\text { School/equivalent }\end{array}$ & 42 & $42 \%$ \\
\hline $\begin{array}{l}\text { Higher Education: Diploma / } \\
\text { Bachelor / Postgraduate }\end{array}$ & 56 & $56 \%$ \\
\hline Total & 100 & $100 \%$ \\
\hline
\end{tabular}

Source: Research Result, 2019

In this study, the level of education of respondents is grouped into four groups, as seen in table 2 , the majority are respondents who receive higher education by $56 \%$ ( 56 people), which is then followed by the high school/vocational/equivalent education group by $42 \%$ (42 people) and the remaining $1 \%$ ( 1 person) each for the elementary school/equivalent and junior high school/equivalent. This group of respondents shows that the majority of people who feel the process and results of "academic" development in Purwakarta are those who have received a secondary education. 
Table 3. Respondents' Occupation

\begin{tabular}{|c|c|c|}
\hline Occupation & Frequency & Percentage \\
\hline Student/College Student & 1 & $1 \%$ \\
\hline Civil servant/Army/Police & 24 & $24 \%$ \\
\hline Private employee & 56 & $56 \%$ \\
\hline Others & 19 & $19 \%$ \\
\hline Total & 100 & $100 \%$ \\
\hline
\end{tabular}

Based on the table above, which shows that the most respondents are private employees, namely $56 \%$ (56 people), then $24 \%$ ( 24 people) as civil servants/military/ police, $1 \%$ ( 1 person) as students/students and others amounting to $19 \%$ (19 people). This table data implies that the presence of private-sector employees as the primary sector supporting regional economies is still dominated, especially in the Purwakarta district area, which is currently being stretched in the development process.

\section{Descriptive Analysis Result}

Classification of research data was made using a frequency distribution with the same interval to facilitate researchers in interpreting research data. Descriptive analysis is intended to see the tendency of the frequency distribution of variables and determine the level of achievement of respondents on each variable. General description of each variable used by the average score obtained using the Weight Means Scored (WMS) technique, with the formula:

Where :

$$
\bar{X}=\frac{\sum x_{i}}{n}
$$

$\mathrm{X}^{-} \quad=$ The average score of respondents

$\sum x_{i}=$ Total score of each respondent's alternative answers

$\mathrm{n} \quad=$ Number of respondents

The calculation results are consulted with the criteria and interpretations as listed in the following table:

Table 4. Variable Average Score Criteria

\begin{tabular}{cc}
\hline Range of Score & Criteria \\
\hline $4,21-5,00$ & Very high \\
$3,41-4,20$ & High \\
$2,61-3,40$ & Enough \\
$1,81-2,60$ & Low \\
\hline $1,00-1,80$ & Very low \\
\hline Source: Research Result, 2019 &
\end{tabular}

Following are the results of a descriptive analysis of the Purwakarta District Branding dimension that includes Brand Awareness, Perceived Quality, Brand Association, Brand Loyalty and Others Asset felt by the Purwakarta community. 
Table 5. Respondents' Answers Regarding Brand Awareness

\begin{tabular}{|c|c|c|}
\hline Brand Awareness & Frequency & Percentage \\
\hline Very Good & 27 & $27 \%$ \\
\hline Good & 57 & $57 \%$ \\
\hline Deficient & 14 & $14 \%$ \\
\hline $\mathrm{Bad}$ & 2 & $2 \%$ \\
\hline Very Bad & 0 & $0 \%$ \\
\hline Total & 100 & $100 \%$ \\
\hline
\end{tabular}

Source: Research Result, 2019

This table shows that the brand awareness criteria found in the development process in Purwakarta are considered by some people to be positive. It can be seen from the brand awareness indicator showing almost mostly good $57 \%$ and very good $27 \%$. Brand Awareness itself is a first step in the brand process to enter the next stages [7]. Overall this dimension can represent that knowledge about a culture built by the Purwakarta government is well known. Through brand awareness owned by the public, especially the community, workers, investors, and government authorities can influence the decision-making process. It is in line with the statement of brand awareness that is usually related to the strength of a brand node or footprint in memory, which can be measured according to the ability of the target audience to identify brands under different conditions [8]. So, a brand is a combination of a name, term, sign, symbol or design or a combination of the whole used to identify an item and service that can differentiate from its competitors.

Therefore, the existing brand awareness of Purwakarta regency which is related to local branding is the Purwakarta regency brand image as an area that originated to rest for retirees to become a new tourist visiting area based on local Sundanese cultural value. The knowledge in the minds of the public about the current condition of Purwakarta regency is an essential capital for the government to be able to optimize other potentials related to the Sundanese culture which have become the main pillars of physical and mental development in the Purwakarta regency government area.

Table 6. Respondents' Answers Regarding Perceived Quality

\begin{tabular}{lcc}
\hline \multicolumn{1}{c}{ Perceived Quality } & Frequency & Percentage \\
\hline Very Good & 32 & $32 \%$ \\
Good & 58 & $58 \%$ \\
Deficient & 9 & $9 \%$ \\
Bad & 1 & $1 \%$ \\
Very Bad & 0 & $0 \%$ \\
\hline \multicolumn{2}{c}{ Total } & $\mathbf{1 0 0}$ \\
\hline \multicolumn{4}{c}{ Source: Research Result, 2019 }
\end{tabular}

Based on the table above, the majority of respondents answered items on perceived quality, which is in the excellent category of 58 people $(58 \%)$. Preferences about brands contained in an object can provide an expectation of the quality of service produced by brand manufacturers, including for the Purwakarta Regency government. Perceived quality, according to Aaker is the quality of commercial products or programs that are real and 
actually already in the minds of the people [8]. The emergence of the tendency of the services displayed by the brand results in the existence of a brand that is very important to be known by the target audience. Therefore, the brand element in the form of perceived quality formed by the Purwakarta regency government can provide its own identity color related to the perceived benefits by the community with a focus on the development of Sundanese culture implemented in various sectors of basic community service programs such as the Gempungan program, the 7 character of Sundanese education system, and health social programs in the form of doctor calls, midwife calls, and ambulance calls.

Table 7. Respondents' Answers Regarding Brand Association

\begin{tabular}{lcc}
\hline \multicolumn{1}{c}{ Brand Association } & Frequency & Percentage \\
\hline Very Good & 70 & $70 \%$ \\
Good & 28 & $28 \%$ \\
Deficient & 2 & $2 \%$ \\
Bad & 0 & $0 \%$ \\
Very Bad & 0 & $0 \%$ \\
\hline \multicolumn{2}{c}{ Total } & $\mathbf{1 0 0 \%}$
\end{tabular}

When the public is uncertain about the brand obtained from an object, it will usually give a "more" association to the appearance or service produced by the object. Brand association, according to Aaker, is defined as a brand that will be strong if it is associated with something quality, especially related to products or programs [7]. The condition of the brand like this will provide credibility of information received by the public, related to brand socialization practices in an area. The brand association formed in Purwakarta Regency shows $70 \%$ at Very Good level while $28 \%$ at Good level. Some forms of brand association displayed by the Purwakarta Regency government include various physical development programs in the form of Sundanese thematic parks, and the locations that become the center of Purwakarta identity such as Sate Maranggi and Plered ceramics artisans areas that have become Purwakarta's trademark.

Table 8. Respondents' Answers Regarding Brand Loyalty

\begin{tabular}{lcc}
\hline \multicolumn{1}{c}{ Brand Loyalty } & Frequency & Percentage \\
\hline Very Good & 27 & $27 \%$ \\
Good & 67 & $67 \%$ \\
Deficient & 6 & $6 \%$ \\
Bad & 0 & $0 \%$ \\
Very Bad & 0 & $0 \%$ \\
\hline \multicolumn{2}{c}{ Total } & $\mathbf{1 0 0}$
\end{tabular}

Based on the table above, the majority of respondents' answers on items about Brand Loyalty are in the first category of 67 people (67\%). As for what is meant by brand loyalty which can be increased into genuine fanaticism [8]. This form of fanaticism can have a good 
effect if the person who manages it does not display local branding elements that can "provoke" the community excessively in neutralizing the uniqueness of an area.

As for normatively, the Purwakarta community will provide recommendations on the existence of the uniqueness of Purwakarta through social media and face-to-face communication as a form of support for the development policy of the Purwakarta district government characterized by Sundanese values. Besides, the brand loyalty owned by Purwakarta regency can be a value of pride for the citizens of Purwakarta whose origins are known as crossing and transit cities for travellers but are now the leading destination for trips in West Java.

\begin{tabular}{|c|c|c|}
\hline Others Asset & Frequency & Percentage \\
\hline Very Good & 45 & $45 \%$ \\
\hline Good & 54 & $54 \%$ \\
\hline Deficient & 1 & $1 \%$ \\
\hline $\mathrm{Bad}$ & 0 & $0 \%$ \\
\hline Very Bad & 0 & $0 \%$ \\
\hline Total & 100 & $100 \%$ \\
\hline
\end{tabular}

Source: Research Result, 2019

Based on the table above, the majority of respondents answered items on Others Asset, which is in the excellent category of 54 people (54\%). According to Aaker, Others Asset is a competitive advantage that is not owned by competitors [7]. Anther form of assets owned by the Purwakarta regency government is Sri Baduga fountain park, the result of the renovation of Buleud lake, which now becomes the largest water park in Southeast Asia by displaying audiovisual elements based on Sundanese technology and culture.

For overall recapitulation results regarding Local Branding variables based on the answers of the respondents in this study can be explained as follows:

Table 10. Respondents' Answers Regarding Local Branding

\begin{tabular}{lcc}
\hline \multicolumn{1}{c}{ Local Branding } & Frequency & Percentage \\
\hline Very Good & 47 & $47 \%$ \\
Good & 52 & $52 \%$ \\
Deficient & 1 & $1 \%$ \\
Bad & 0 & $0 \%$ \\
Very Bad & 0 & $0 \%$ \\
\hline \multicolumn{2}{c}{ Total } & $\mathbf{1 0 0}$
\end{tabular}

Based on the table above, the majority of respondents who answer items on Local Branding in the excellent category (Very Good) are 52 people (52\%). Conceptually, Johanson and Ronkainen state in [9] that people prefer local brands for everyday products. It is consistent with the results of interviews with people who visit Purwakarta who say that Purwakarta regency now has a new identity as a new tourist destination by displaying a variety of developmental Sundanese that are packaged in the form of physical and mental development programs around Purwakarta area. 
Basically, an object has a brand image, both with and without nation branding. Each region has a name and a unique characteristic in the minds of people or society so that the area has a brand. A local brand is the overall perception of a community in the minds of stakeholders that includes elements of people, places, culture/languages, history, food, fashion, development programs, and so on. Thus, with or without conscious effort in the form of local branding, each region has a value in the minds of the people, whether it is strong or weak, clear or vague. Local branding is an effort to make an area unique and ensure that an individual image can reach and immerse in the minds of the target groups. Usually, local branding involves promoting the image of the success of a program to the community to get positive values socially, politically, economically, culturally, to create a superior competitive atmosphere.

By using branding, Purwakarta local branding confirms or changes the behavior, attitudes, identity, or image of the region employing positive communication. The local branding offered by Purwakarta regency in the form of tangible products or services, but something that represents and covers various factors and associations, such as geography (centers), tourist attractions, natural resources, local products, race people, ethnic, historical, cultural, linguistic and inspirational groups based on technology and culture.

\section{CONCLUSION AND SUGGESTION}

Based on the results of the analysis and discussion showed that the majority of respondents gave a positive assessment of aspects of local branding that formed in Purwakarta district with an average value above $50 \%$. It can occur because most respondents have felt directly or indirectly from the benefits of development based on the values of Sundanese as the local identity of the Purwakarta community in living the life of the nation and state.

As for suggestions on the implementation of local branding implemented in policies and or programs of Purwakarta district government in building Sundanese cultural identity in aspects of physical and mental development, Purwakarta regency government should pay more attention to the formation of cultural characters that are reinforced by Islamic religious studies so that the development of Sundanese cultural values that are currently being done not deviate from religious values and in terms of developing social media as a means of communication and information Purwakarta regency government should be able to coordinate and communicative with the community in solving a problem that concerns the common public interest.

\section{REFERENCES}

[1] P. Rufaidah, "Branding strategy berbasis ekonomi kreatif: triple helix vs quadruple helix," in Branding Strategy Berbasis Industri Kreatif Fashionn, no. 1, Bandung, 2015.

[2] M. Rachmayanti and N. Rina, "Analisis Strategi Promosi Dalam Pengembangan Pariwisata," J. Komun. dan Media, vol. 2, no. 2, pp. 1-17, 2018.

[3] Suharyati, "Pengaruh Persepsi Kecocokan dan Kredibilitas Perusahaan Terhadap Asosiasi Merek dan Intesi Membeli,” Commun. Spectr., vol. 1, no. 1, pp. 1-16, 2011.

[4] B. Maral, "Effects of Global and Local Branding on Consumer Perception: an Application," Dokuz Eylul Universitesi, 2011.

[5] L. Wood, "Brands and brand equity: definition and management," Manag. Decis., vol. 38, no. 9, pp. 662-669, 2000.

[6] A. Bajari, Metode penelitian komunikasi: prosedur, tren, dan etika. Bandung: PT Simbiosa Rekatama Media, 2015. 
[7] Sugiyono, Metode Penelitian Kuantitatif, Kualitatif dan R\&D. Bandung: Alfabeta, 2010 .

[8] S. A. Wasesa, Political Branding \& Public Relations. Jakarta: PT. Gramedia Pustaka Utama, 2011.

[9] K. L. Keller, Strategic Brand Management: Building, Measuring, and Managing Brand Equity, Global Edi. Boston: Perason Education Limited, 2013.

[10] F. Tjiptono, Pemasaran Jasa. Yogyakarta: Andi Offset, 2014. 